\title{
The invasive coral Oculina patagonica has not been recently introduced to the Mediterranean from the western Atlantic
}

\author{
Karine Posbic Leydet ${ }^{*}$ and Michael E Hellberg
}

\begin{abstract}
Background: Effective policies, management, and scientific research programs depend on the correct identification of invasive species as being either native or introduced. However, many species continue to be misidentified. Oculina patagonica, first recorded in the Mediterranean Sea in 1966, is believed to have been introduced in anthropogenic times and expanding in a west to east direction. However, its present identification and status as a recently introduced species remain to be explored. In this study, we used multi-locus genetic data to test whether O. patagonica in the Mediterranean has been recently introduced from the western North Atlantic.

Results: We found no genetic or historical demographic evidence to support a recent introduction of $O$. patagonica from the western North Atlantic or an expansion across the Mediterranean. Instead, Mediterranean and Atlantic populations are genetically distinct and appear to have begun diverging about 5 Mya. We also found evidence of a fossil record of Oculina spp. existing in the eastern North Atlantic millions of years before the present.

Conclusions: Our results suggest that Mediterranean populations of $O$. patagonica have long been isolated from the western Atlantic, either in undetectable numbers or overlooked and undersampled sites and habitats, and have only recently been expanding to invasive levels as a result of environmental changes. Accurate identification of species' invasive statuses will enable more effective research programs aimed at better understanding the mechanisms promoting the invasive nature of species, which can then lead to the implementation of efficient management plans.
\end{abstract}

Keywords: Introduction, Native invasive, Range expansion, Oculina, Mediterranean Sea

\section{Background}

The number of introduced and invasive species is rising [1], rapidly altering ecosystems around the world, often by out-competing and displacing native species $[2,3]$. Beyond their direct impacts on native species, these invasive species can indirectly lead to cascading effects within a community [4], thereby threatening ecosystem functions. Studies concerning successful introduced and invasive species are key to exploring the mechanisms by which these species adapt to and alter their new environment. However, determining whether a species is native or introduced is first necessary, and this is not always an easy task.

\footnotetext{
* Correspondence: kposbi1@lsu.edu

Department of Biological Sciences, Louisiana State University, Baton Rouge, LA 70803, USA
}

(c) 2015 Leydet and Hellberg; licensee BioMed Central. This is an Open Access article distributed under the terms of the Creative Commons Attribution License (http://creativecommons.org/licenses/by/4.0), which permits unrestricted use, distribution, and reproduction in any medium, provided the original work is properly credited. The Creative Commons Public Domain Dedication waiver (http://creativecommons.org/publicdomain/zero/1.0/) applies to the data made available in this article, unless otherwise stated.
Introduced species can be mislabeled as native due to taxonomic misidentification [5,6]. Native species can also be misidentified as introduced. Zenetos et al. [7] reports that $23 \%$ of the 963 reportedly introduced species in the Mediterranean have been misidentified and therefore misclassified. Of the remaining 745 species, $13 \%$ remain questionable due to insufficient information and unresolved taxonomic status and many others maintain a "cryptogenic" status, as they cannot be reliably assigned to either "native" or "introduced" [8]. In other cases, species are mislabeled as introductions due to a lack of historical records of an obvious presence [7,9-11]. These misidentifications can have profound effects on the assessment of species status [12].

Invasive species are often assumed to have been introduced $[9,10]$, however species can become invasive within their native range, usually due to human-mediated 
disturbances [13-15]. Effective policies, management, and scientific research programs depend on the correct identification of invasive species as being either native or introduced. Whereas the management of introduced invasives is more concerned with the introduction scenario and conditions enabling subsequent expansion, management of native invasives should ideally be more focused on the changes in environmental conditions that facilitate their invasive characteristics in their native habitat $[11,16]$. Therefore, to implement more effective research and management programs for invasive species, an invasive species must first be identified as either introduced or native.

An introduced invasive population can be distinguished from native invasive populations in several ways. An expanding introduced population is expected to be genetically similar to an external source population where it originated [17]. In contrast, a native invasive population will often be genetically distinct from populations outside its range $[9,18]$. Inferring the divergence time between populations from different ranges can also establish whether or not an invasive population coincides with a recent introduction (estimated divergence time will overlap with the present day), or whether it predates anthropological times (older divergence time) [19-21]. Finally, the presence of a fossil record for an invasive species or its progenitors can indicate that the species has a long presence in a particular region $[10,11]$.

Corals of the genus Oculina were originally described from the southeastern coast of North America [22]. Although several nominal species exist in this region, Eytan et al. [23] found no genetic differences among shallow water populations of four named taxa (O. arbuscula, $O$. diffusa, $O$. varicosa, and, O. robusta), suggesting that these designations do not represent genetically distinct species. We will refer to these taxa collectively as "western Atlantic (WA) Oculina spp".

An additional extant species, Oculina patagonica, occurs in the waters of the Mediterranean Sea [24,25]. O. patagonica was originally described from fossils from the southeastern coast of South America [24] (see Additional file 1: Figure S1), however reports of live specimens from South America are lacking and a recent survey of fouling communities in Argentinian ports failed to find any evidence of this species [26]. O. patagonica has been thought to have been introduced in anthropogenic times from the western south Atlantic to the western Mediterranean via shipping. O. patagonica was first reported from the harbor of Savona (Gulf of Genoa), Italy in 1966 [24] and soon after from the harbor of Alicante, Spain [27], $1000 \mathrm{~km}$ away. From the western Mediterranean, it is thought to have spread easterly, and while today reports of this coral in many locations reflect populations limited in number and range, populations in
Spain, Greece, and Israel are well-established and expanding [24,25,27-38].

Alternatively to being recently introduced, O. patagonica may be a native species that has only recently been detected due to a recent expansion. The original description and identification of $O$. patagonica is based on fossil remains, not living counterparts [24]. This is problematic, as morphology is a poor delineation of coral species in general $[39,40]$ and Oculina species in particular [23] (see Additional file 1: Figure S1). Given that no known populations of $O$. patagonica presently exist outside the Mediterranean, populations of WA Oculina spp. are currently the most likely source for a recent introduction.

Here, we ask whether O. patagonica has been recently introduced into the Mediterranean from the western North Atlantic, or whether it is an eastern Atlantic native only newly become invasive. First, we use multilocus genetic data to determine whether O. patagonica is genetically similar to or distinct from WA Oculina spp. If $O$. patagonica has been recently introduced from the western North Atlantic, we expect these populations to be genetically similar. Second, we estimate divergence time between O. patagonica populations and WA Oculina sp. populations and evaluate whether the estimate is consistent with an anthropogenic introduction. We also search museum collections for evidence of a fossil record of Oculina spp. in the eastern Atlantic, which would suggest that Oculina has a long history in this region. Finally, we explore whether patterns of genetic diversity in O. patagonica are consistent with a west to east expansion across the Mediterranean from a single point of introduction.

\section{Results}

\section{Genetic diversity and population subdivision}

We genotyped 122 samples of Oculina spp. from the western North Atlantic $(\mathrm{n}=56)$ and Mediterranean $(\mathrm{n}=66)$ for the mitochondrial COI gene and five nuclear genes. Western North Atlantic populations included North Carolina, Daytona Beach, FL, Cape Florida, FL, Panama City, FL, and Bermuda. Mediterranean populations of O. patagonica included Spain, Italy, Greece, Lebanon, and Israel (Figure 1). A total of 17 individuals from Spain, Greece, and Israel were removed from the dataset because they shared a multilocus genotype with another individual in the same population, so the final nuclear data set contained 105 individuals (see Additional file 2: Table S1). All O. patagonica samples shared the same COI haplotype common to $98 \%$ of WA Oculina spp. (see Additional file 3: Figure S2). Because $\mathrm{COI}$ was nearly invariant, as expected due to the conservation of anthozoan mitochondrial DNA [41], we used only the five nuclear genes in all analyses. GARD did not detect recombination within any of these five gene regions. 


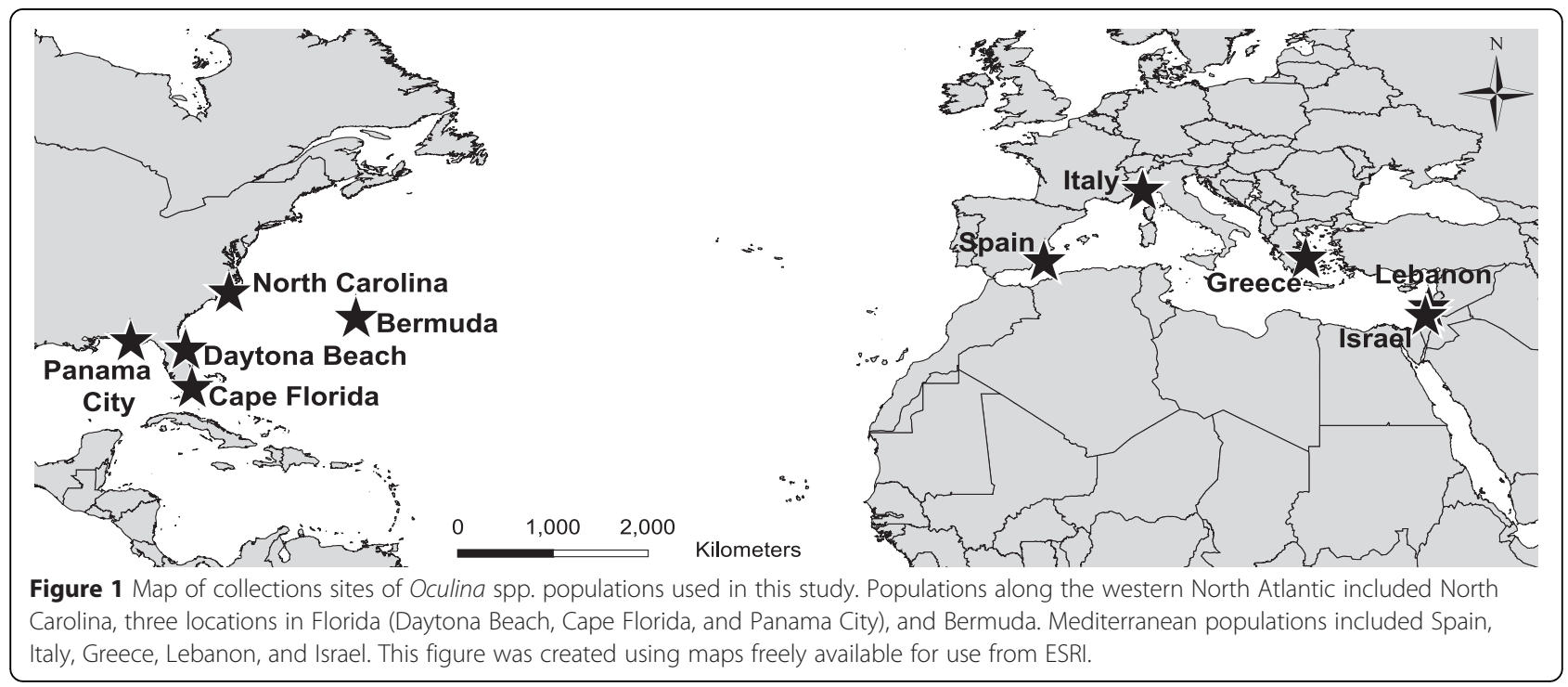

Haplotype networks revealed that, while populations in the western North Atlantic and the Mediterranean share many alleles at all five loci, all markers possess several private alleles unique to just one region (Figure 2). Specifically, for three genes (p14, p62, and p302), over half of the total alleles for each of those genes are unique to the Atlantic. In contrast, the Mediterranean harbors fewer private alleles for all genes (Figure 2). T-tests revealed that allelic richness was greater in the western North Atlantic than in the Mediterranean (Figure 3a), although this difference is not large (western North Atlantic mean =
$2.38 \pm 0.09$; Mediterranean mean $=2.14 \pm 0.09$ ), and therefore likely not biologically significant. Observed heterozygosity did not differ between the western Atlantic and Mediterranean (Figure 3a), nor did allelic richness or observed heterozygosity between western Mediterranean (Spain and Italy) and eastern Mediterranean (Greece, Lebanon, and Israel) populations (Figure 3b).

AMOVA revealed significant subdivision among all populations, as well as between western North Atlantic and Mediterranean populations (Table 1). However, AMOVA conducted on Mediterranean populations alone revealed

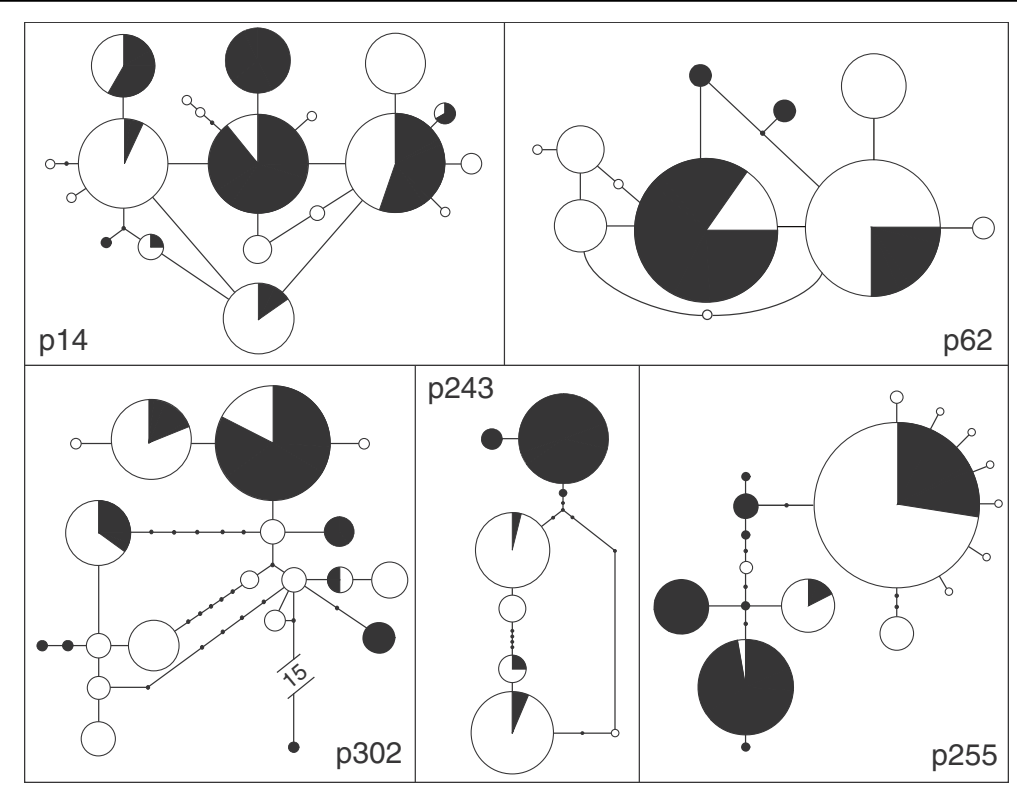

Figure 2 Haplotype networks of the five nuclear genes used in this study. Each pie graph represents an allele and the shades represent the proportion of individuals from the different populations that share that particular allele. White represents western North Atlantic Oculina spp. populations. Black represents Mediterranean populations of Oculina patagonica. Line segments connecting alleles represent a single mutation step separating the alleles, and small black dots represent inferred alleles not present in our dataset. 


\section{a Between Western Atlantic \\ 3. and Mediterranean}

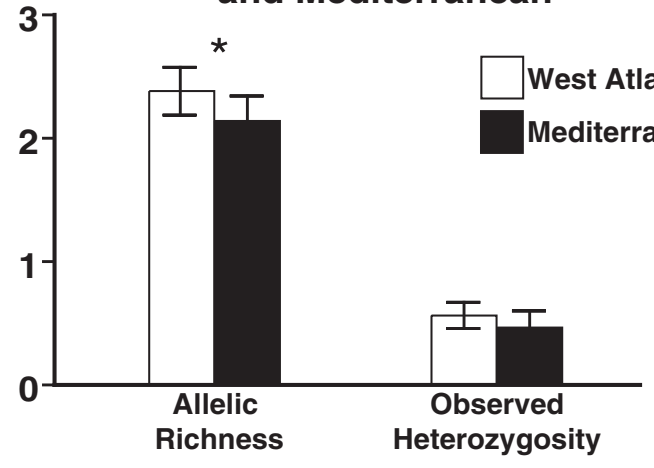

b

Within Mediterranean

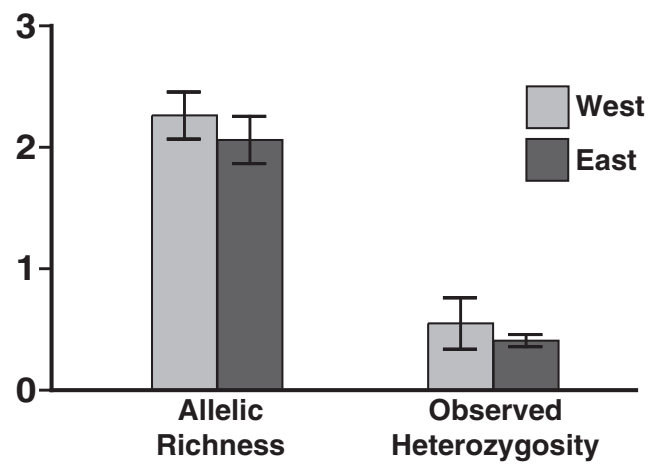

Figure 3 Comparison of allelic richness and observed heterozygosity. Means of allelic richness and observed heterozygosity compared between western North Atlantic and Mediterranean populations of Oculina spp. (a), and between western Mediterranean (Spain and Italy) and eastern Mediterranean (Greece, Lebanon, and Israel) Oculina patagonica populations (b). Bars represent standard deviations. Asterisks represent significant differences as determined by t-tests.

no significant subdivision, either among populations or between the west and east (Table 2). Instead, variation within populations accounted for $98 \%$ of observed variation. These findings suggest that while the western North Atlantic populations are genetically distinct from those in the Mediterranean, populations within the Mediterranean are genetically similar to each other.

To further test for more subtle genetic differentiation, we used STRUCTURE 2.3.4 [42] and the Evanno method [43] implemented in STRUCTURE HARVESTOR [44] to detect differentiated populations $(k)$. When all populations were analyzed according to the Evanno method [43], the most likely $k$ was two. The visual representation of these

Table 1 Analysis of molecular variance performed for all populations

\begin{tabular}{llll}
\hline Source of variation & \% variation & F-value & P-value \\
\hline Within Populations & $58.9 \%$ & 0.411 & $\mathrm{NA}$ \\
Among Populations & $8.4 \%$ & 0.125 & $<<0.01$ \\
Among Groups & $3.3 \%$ & 0.328 & $<<0.01$ \\
\hline
\end{tabular}

Groups $=$ western North Atlantic populations and Mediterranean populations. Significant P-values are in bold. two genetic clusters (Figure 4a) shows that the western North Atlantic, including Bermuda, and Mediterranean form distinct genetic clusters. At $k=3$, STRUCTURE recovered the two main genetic clusters previously found in the western North Atlantic [23] in addition to the Mediterranean cluster (Figure 4b). When analyzing the Mediterranean populations alone, the Evanno method [43] determined that the mostly likely $k=4$, although the $\Delta k^{\prime}$ s for the range of $k$ tested were very low and similar, suggesting a lack of biologically meaningful clusters. Indeed, the visual representation fails to show any clear individual assignments and geographic association of these clusters, consistent with the Mediterranean

Table 2 Analysis of molecular variance performed for Mediterranean populations only

\begin{tabular}{llll}
\hline Source of variation & \% variation & F-value & P-value \\
\hline Within Populations & $98.0 \%$ & 0.02 & NA \\
Among Populations & $1.4 \%$ & 0.014 & 0.256 \\
Among Groups & $0.6 \%$ & 0.006 & 0.101 \\
\hline
\end{tabular}

Groups = West (Spain and Italy) and East (Greece, Lebanon, and Israel). 

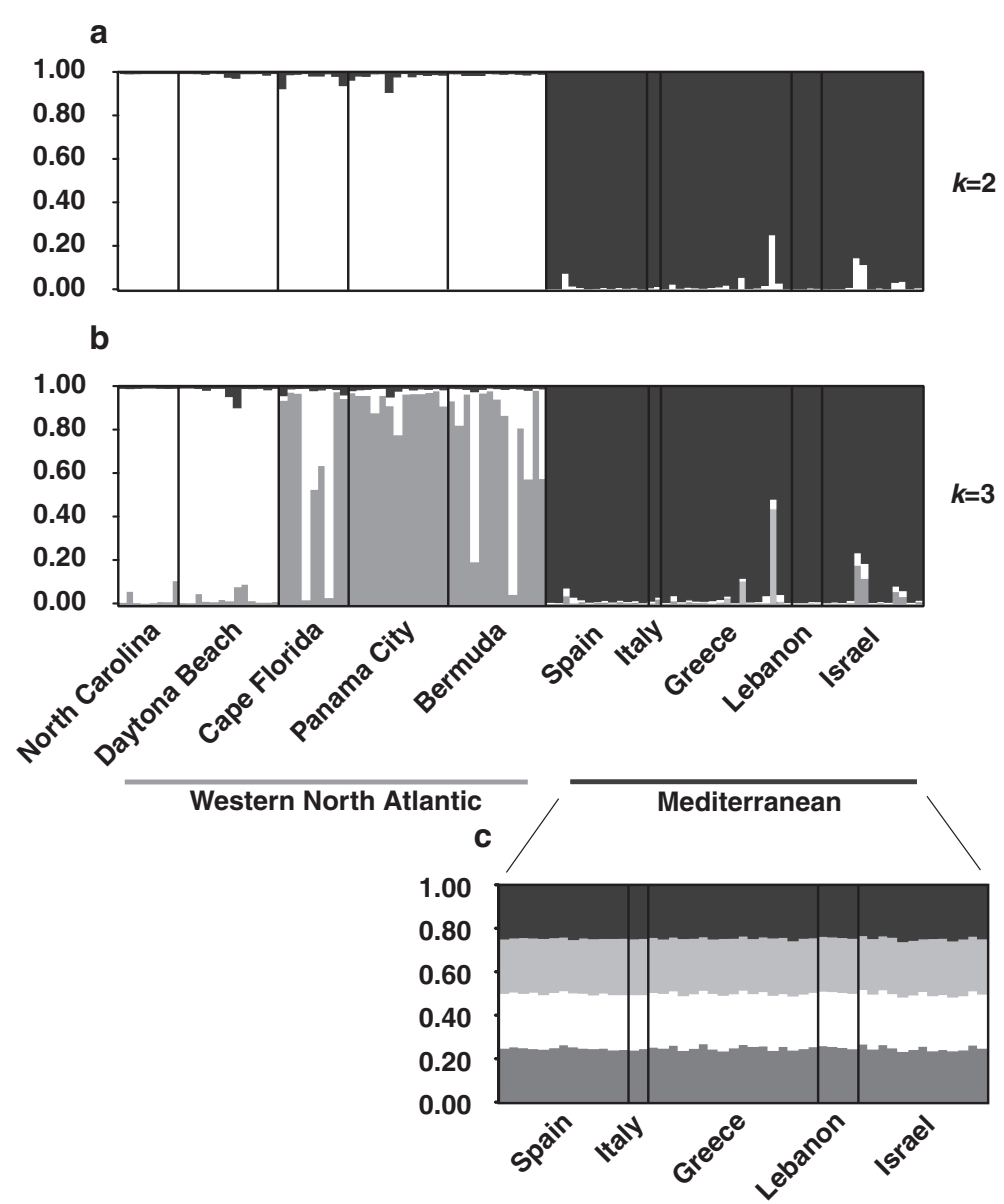

Figure 4 STRUCTURE bar plots. Each bar represents an individual. Individuals are grouped by populations along the $x$-axis. Along the $y$-axis is the probability of assignment to a particular population represented by different shades. When analyzing all populations, the Evanno method [43] determined that the mostly likely number of genetic clusters or populations ( $k$ ) was 2 (a). The visual representation of these two populations (a) shows that individuals cluster geographically (western North Atlantic versus Mediterranean), and that the Mediterranean populations are genetically distinct from the western North Atlantic populations. At $k=3 \mathbf{( b )}$, the two main genetic clusters previously found in the western Atlantic [23] were recovered, while maintaining a genetically differentiated Mediterranean cluster. When analyzing the Mediterranean populations alone (c) there is no clear genetic structure across the Mediterranean, even though the Evanno method [43] determined that the most likely number of populations ( $k$ ) was 4.

populations being genetically similar across the region (Figure 4c). STRUCTURAMA runs corroborated these STRUCTURE results.

\section{Divergence time}

We estimated the time of divergence between western North Atlantic and Mediterranean populations using IMa [45]. We found that the populations diverged $5.4 \pm 2.0$ million years ago, long before recent times (Figure 5). The best supported IM model (Table 3) had two parameters for population size and two for migration, suggesting that migration has played a role in the history of WA Oculina spp. populations and O. patagonica in the Mediterranean. Models of strict isolation were thousands of times less likely than the best model. Migration from the western North Atlantic to the Mediterranean was greater (0.00139 [90\% highest posterior density interval $=0.0008-0.0024]$ ) than the reverse migration $(0.000042$ [0-0.002]) (Figure 6). In fact, the next best model was one in which migration from the Mediterranean to the western North Atlantic was equal to 0 .

\section{The fossil record}

We explored online databases of museum collections for a fossil record of Oculina spp. in the eastern Atlantic and/or the Mediterranean. We found 16 fossil specimens of Oculina spp. in two independent museum collections: the Smithsonian National Museum of Natural History's Department of Invertebrate Zoology (see Additional file 1: Figure S1), and the Muséum National d'Histoire Naturelle Paléontologie. All specimens originated from north-northwestern France. The estimated ages of the 


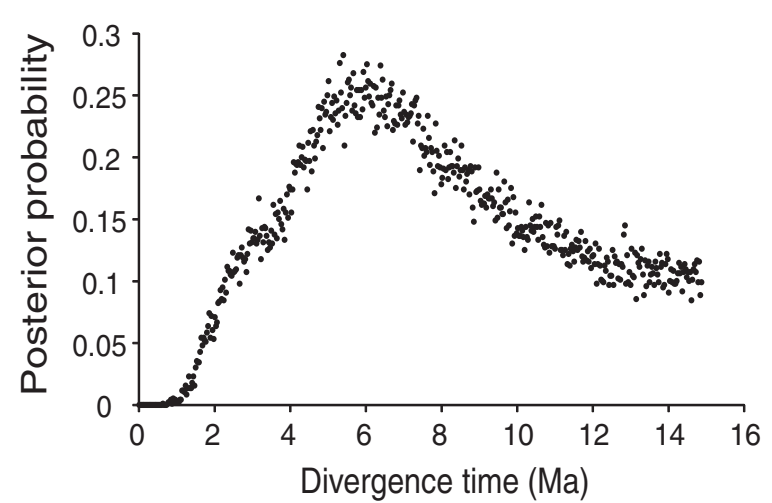

Figure 5 Posterior probability distribution for divergence times between western North Atlantic and Mediterranean populations of Oculina spp. Divergence time $=5.4 \pm 2.0$ million years ago.

specimens range broadly, with most from the Eocene (56-34 Ma) to the Miocene (23.03-5.332 Ma) (Table 4).

\section{Population expansion within the Mediterranean}

To test for a past population expansion within the Mediterranean Sea, we used LAMARC 2.0 [46]. The overall population growth rate across all genes and replicates was -65 , indicating that the population has not been expanding. We treated the Mediterranean as a single population, since we did not detect significantly differentiated populations within the Mediterranean (Figure 4c). We also performed analyses on the three Mediterranean populations with the largest sampling sizes (Spain, Greece, and Israel) separately, and found similar results.

\section{Discussion}

Oculina patagonica has not been recently introduced into the Mediterranean

Our data show that Mediterranean populations of $O$. patagonica are genetically distinct from WA Oculina spp. populations (Figure 4a). While Oculina spp. populations from either side of the Atlantic share many alleles for all markers, there were notable private alleles for both regions (Figure 2). Contrary to expectations for a recently

Table 3 Evidence ratios and ranks of all possible isolation with migration models

\begin{tabular}{|c|c|c|c|c|c|c|c|}
\hline Model & k & $\log (P)$ & AIC & $\Delta \mathbf{i}$ & Model likelihoods & wi & Evidence ratio (best model) \\
\hline ABADE & 4 & -1.770 & 11.540 & 0.000 & 1.000 & 0.364 & \\
\hline$A B C O D$ & 4 & -1.953 & 11.906 & 0.366 & 0.833 & 0.303 & 1.200 \\
\hline FULL & 5 & -1.446 & 12.891 & 1.351 & 0.509 & 0.185 & 1.965 \\
\hline ABBDE & 4 & -2.723 & 13.446 & 1.906 & 0.386 & 0.140 & 2.593 \\
\hline ABADD & 3 & -7.920 & 21.840 & 10.300 & 0.006 & 0.002 & 172.431 \\
\hline ABBDD & 3 & -8.351 & 22.702 & 11.163 & 0.004 & 0.001 & 265.416 \\
\hline $\mathrm{ABCDD}$ & 4 & -7.358 & 22.715 & 11.175 & 0.004 & 0.001 & 267.094 \\
\hline AAADE & 3 & -8.398 & 22.795 & 11.255 & 0.004 & 0.001 & 277.994 \\
\hline AACDE & 4 & -7.866 & 23.731 & 12.192 & 0.002 & $<10^{-3}$ & 443.989 \\
\hline AACDD & 3 & -10.835 & 27.671 & 16.131 & $<10^{-3}$ & $<10^{-3}$ & 3182.429 \\
\hline AAADD & 2 & -12.542 & 29.084 & 17.545 & $<10^{-3}$ & $<10^{-3}$ & 6452.997 \\
\hline $\mathrm{ABCD} 0$ & 4 & -195.238 & 398.476 & 386.936 & $<10^{-50}$ & $<10^{-50}$ & $<10^{50}$ \\
\hline $\mathrm{ABCOO}$ & 3 & -228.380 & 462.760 & 451.220 & $<10^{-50}$ & $<10^{-50}$ & $<10^{50}$ \\
\hline ABA00 & 2 & -234.240 & 472.480 & 460.941 & $<10^{-100}$ & $<10^{-100}$ & $<10^{100}$ \\
\hline ABBOO & 2 & -249.428 & 502.855 & 491.315 & $<10^{-100}$ & $<10^{-100}$ & $<10^{100}$ \\
\hline AACOO & 2 & -263.32 & 530.648 & 519.108 & $<10^{-100}$ & $<10^{-100}$ & $<10^{100}$ \\
\hline AAA00 & 1 & -272.668 & 547.337 & 535.797 & $<10^{-100}$ & $<10^{-100}$ & $<10^{100}$ \\
\hline
\end{tabular}

Evidence ratios and ranks calculated using model-based selection. For each model, the first three letters represent the three population parameters $\left(\theta_{1}, \theta_{2}\right.$, and ancestral $\theta$ ), and the last two letters represent the two migration parameters $\left(m_{1}\right.$ and $\left.m_{2}\right)$, in that order. The best model is the first model listed (ABADE) followed by the next best models in descending order. 


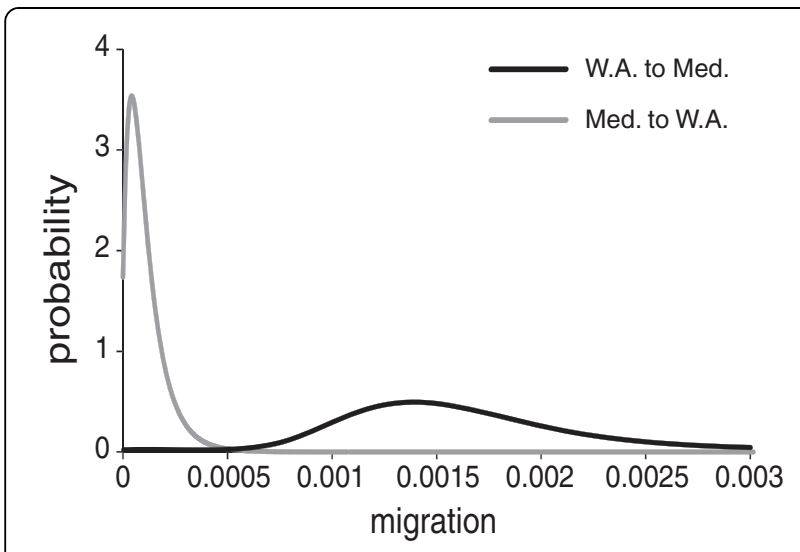

Figure 6 Posterior probability distributions for migration between western North Atlantic and Mediterranean populations of Oculina spp. Posterior probability distribution for migration (average number of migrants per 1000 generations) scaled by neutral mutation rate between western North Atlantic and Mediterranean populations of Oculina spp. Migration from the western North Atlantic to the Mediterranean was 0.00139 (90\% highest posterior density interval $=$ 0.0008-0.0.0024). Migration from the Mediterranean to the western North Atlantic was $0.000042(0-0.002)$.

introduced and expanding species, Mediterranean $O$. patagonica harbors genetic diversity on par with longestablished WA Oculina spp. populations (Figure 3a). Our IMa results reveal that O. patagonica and WA Oculina spp. populations diverged millions of years ago (Figure 5). Taken together, our results suggest that while O. patagonica populations from the Mediterranean are closely related to WA Oculina spp. populations, they are genetically differentiated from them and have not been introduced into the Mediterranean from the western North Atlantic in anthropogenic times. Although we did not include Oculina spp. samples from the Caribbean, Bermuda likely represents the Caribbean given that in other broadcast spawning corals little genetic variation has been found between the Caribbean and the western Atlantic [47].

While there are many similar examples of misidentified native species $[9,11,19]$, and see below, contrary to our findings for O. patagonica, many species have been introduced into the Mediterranean. A well-known example is the green alga, Caulerpa taxifolia [48]. Using nuclear sequence data, Jousson et al. [49] determined that this species was introduced into the Mediterranean from an aquarium in Monaco, which maintained an algal strain of unknown geographical origin cultivated in western European aquaria. Mitochondrial sequence data was used to determine that a Mediterranean clade of sea squirts, Clavelina lepadiformis, was recently introduced from eastern Atlantic populations [5]. The Mediterranean Sea has experienced an influx of introduced species in recent decades [50], which has been attributed to increased sea temperatures, along with coincident range expansions of introduced species and range shifts of native ones [51].

\section{Where did $O$. patagonica originate?}

The original hypothesis for the origin of Mediterranean $O$. patagonica suggested that, based on its identification, it must have been introduced from South America, where the only evidence (fossils) of this species existing outside the Mediterranean resides [24]. However, reports of live specimens of O. patagonica in South America are lacking, and a recent survey of fouling communities in Argentinian ports failed to find any evidence of this species [26]. If

Table 4 Museum records of fossil specimens of Oculina spp. from the eastern Atlantic

\begin{tabular}{|c|c|c|c|c|}
\hline Museum & Record number & Species & Location & Epoch or age \\
\hline \multirow[t]{8}{*}{ Smithsonian National Museum of Natural History } & USNM 64539 & Oculina sp. & Indre-et-Loire, France & Eocene-Serravallian \\
\hline & USNM | 80806 & Oculina crassoramosa & France & Miocene \\
\hline & USNM | 80807 & Oculina crassoramosa & France & Miocene \\
\hline & USNM | 80808 & Oculina solanderi & Oise, France & Lutetian \\
\hline & USNM I 80809 & Oculina raristella & France & Eocene \\
\hline & USNM | 80810 & Oculina sp. & Oise, France & Lutetian \\
\hline & USNM | 80811 & Oculina sp. & Seine-et-Oise, France & Lower Lutetian \\
\hline & USNM | 80812 & Oculina sp. & Eure, France & Lutetian \\
\hline \multirow[t]{8}{*}{ Muséum National d'Histoire Naturelle } & MNHN-F-M00169 & Oculina gemmata & Calvados, France & Bathonian \\
\hline & MNHN-F-M00170 & Oculina neustriaca & Calvados, France & Bathonian \\
\hline & MNHN-F-M00326 & Oculina crassoramosa & Indre-et-Loire, France & Langhian \\
\hline & MNHN-F-M00598 & Oculina crassoramosa & Indre-et-Loire, France & Langhian \\
\hline & MNHN-F-M00675 & Oculina raristella & Oise, France & Lutetian \\
\hline & MNHN-F-M00745 & Oculina crassoramosa & Indre-et-Loire, France & Langhian \\
\hline & MNHN-F-M00749 & Oculina crassoramosa & Indre-et-Loire, France & Langhian \\
\hline & MNHN-F-M01113 & Oculina explanata & Sarthe, France & Cenomanian \\
\hline
\end{tabular}


living O. patagonica are not present in the western South Atlantic, they could not have been recently introduced into the Mediterranean from this region. Although it is possible that $O$. patagonica still resides in the western South Atlantic in low undetected numbers or habitats, there are no grounds to suggest $O$. patagonica recently originated from South America until (if) those specimens are found.

If $O$. patagonica has not recently travelled east across the Atlantic to the Mediterranean, then where did it originate? We found records for 16 fossil specimens of Oculina spp. from France (Table 4). Along with these multiple records from two museums, Oculina spp. fossils have also been reported from the Danish Basin during the Middle Danian (about 64 Mya) [52] and south Aquitaine, France, during the Late Oligocene (about 25 Mya) [53]. Although all of these fossils originated from outside of the Mediterranean, they suggest that the genus Oculina has long been present in the eastern North Atlantic.

A long presence in the eastern Atlantic is consistent with our genetic data, which suggest that the western North Atlantic and Mediterranean populations diverged 5.4 \pm 2.0 million years ago (Figure 5). This coincides with the Late Miocene Messinian Salinity Crisis (5.33 Ma), when sea levels in the Mediterranean basin dropped, separating it from the Atlantic and killing off many marine species $[54,55]$. The asymmetric migration in the history of Oculina spp. (Figure 6), with a greater inferred migration from the western North Atlantic to the Mediterranean, may reflect the repopulation of the Mediterranean with Atlantic aquatic fauna following the Messinian Salinity Crisis [54-56]. However, an ancient introduction would likely leave behind a fossil record, and we found no Oculina spp. fossils from within the Mediterranean. This may be due to undiscovered or undocumented fossils, but could also indicate that O. patagonica was more recently introduced from elsewhere, likely the eastern North Atlantic [57]. Our finding of no genetic structure within the Mediterranean also suggests that it may not have an ancient presence there. Further survey efforts are needed to determine whether extant Oculina spp. populations exist in the eastern North Atlantic, and whether they are the source of $O$. patagonica.

Another hypothesis for the origin of O. patagonica lies along the western coast of Africa. Schizoculina africana has both a fossil and living presence in Cape Verde $[58,59]$. Originally known as Oculina africana, this species was split to form a new genus (Schizoculina) due largely to a unique way in which polyps bud $[24,60]$. However, dual modes of budding have been reported within a single coral species [61] and may therefore not be a good diagnostic trait to differentiate species. Future genetic work is needed to investigate whether Schizoculina africana and Oculina patagonica are in fact conspecific, and whether $O$. patagonica originated from the northwestern coast of Africa.

Oculinidae is a taxonomically confused family $[39,62]$ in need of a more in depth genetic study to better understand the relationships between and within the genera and species in this family. As indicated by mitochondrial and nuclear genes, Oculinidae is paraphyletic, and Oculina is more closely related to some members of different families (Faviidae, Caryophylliidae, and Rhizangiidae) than to some members of its own family. Thus, representatives from some extra-familial genera with which Oculina has sometimes been allied (Astrangia of the Rhizangiidae, Cladocora of the Caryophylliidae) [24] should also be included in future efforts to trace the origins and taxonomic classification of Oculina patagonica.

\section{The geographical expansion of 0 . patagonica in the Mediterranean}

Direct observations testify to O. patagonica's increase in abundance at shallow depths at many localities in the Mediterranean over the past 20 years [32,34]. Along the Catalan coast, the species spread from just one location in 1992 to 43 by 2010, a rate of northward expansion of $22 \mathrm{~km}$ per year [32]. In 2005, a few colonies of O. patagonica were first reported from a single site in the Saronikos Gulf of the Aegean Sea [29]. By 2009, O. patagonica could be found in 45 of 54 surveyed sites in this region [34].

Fine et al. [25] proposed that O. patagonica has been expanding west to east, just as first reports of its presence have. Our tests, however, did not detect a genetic signal of expansion across the Mediterranean. While this may result from low power, the proposed west to east spread is also opposite to most other range expansions in the Mediterranean, which have occurred in a north-westward direction in response to increasing sea temperature [51]. Because in the Mediterranean temperature increases from east to northwest, and rising temperatures have been proposed to be promoting the range expansion of O. patagonica [32], a west to east expansion would be contrary to expectation, unless it was introduced into the western Mediterranean Sea, which our tests failed to support. Furthermore, some recent first reports have come from the western Mediterranean [30], and O. patagonica was first reported from the Levant prior to Greece [28,29,35]. Finally, if $O$. patagonica was first established in the western Mediterranean and only more recently in the east, then the western populations would likely harbor more genetic diversity; however, we found similar levels of genetic diversity across the Mediterranean. Alternatively, O. patagonica could be moving into the Mediterranean from elsewhere in the eastern North Atlantic, but in sufficient numbers to not leave a genetic signature of expansion.

Despite lack of evidence for a demographic expansion from west to east, it appears that O. patagonica's invasive 
behavior may have "expanded" west to east. Serrano et al. [32] report an expansion along the Spanish coast from 1992-2010. Salomidi et al. [34] reported a later spread along the coast of Greece from 2005-2009. While this eastward trend may owe to chance, it could also be due to human-mediated modifications of shallow coastal habitats occurring earlier in the west, or limiting conditions in the east [25] that populations have adapted or acclimated to overtime [63].

\section{O. patagonica is native species recently turned invasive}

It seems most likely that $O$. patagonica has always existed somewhere in the eastern Atlantic and has recently become invasive in the Mediterranean, expanding in local regions in response to environmental change [51], likely mediated by human-modifications of coastal habitats $[32,34]$. In a similar way, the snowflake octocoral, identified in Hawai'i as Carijoa riisei, was believed to have been recently introduced from its native range in the Caribbean. However, Concepcion et al. [9] used mitochondrial and nuclear sequence data to compare the Hawaiian populations to worldwide populations of Carijoa and found that the Hawaiian populations were not genetically similar to the Caribbean and therefore did not originate from there. The originally misidentified native diatom Didymosphenia geminata remained undetected in its native range for decades before blooms were documented in the 1990s [64]. Today, this native invasive alga is rapidly expanding locally in response to environmental changes $[11,64]$. The gastropod, Littorina littorea, has long been thought to have been recently introduced to North American from Europe. However, both mitochondrial and nuclear sequence data indicated that the North American and European populations diverged thousands of years ago. This native gastropod is also believed to have begun expanding along the coast of New England as a result of environmental changes [19].

Identifying additional mechanisms that facilitate invasiveness in O. patagonica will require work aimed at better identifying and characterizing the source populations and population dynamics of well documented locally expanding O. patagoncia populations within the Mediterranean, such as along the coasts of Spain [32] and Greece [34]. The conditions at these invasion localities can then be compared to conditions where O. patagonica exits but is not to date invasive to better understand the mechanisms driving its expansion. Such studies may also aid in assessing the future of the newly discovered coral species, Oulastrea crispate, in the Mediterranean as it too is expected to rapidly expand its range [65].

Additional studies are also needed to better understand the ecological consequences of the expansion of Oculina patagonica. While marine range shifts may occur at a slower rate than marine introductions, their potential effects on the community are likely to be just as significant [66]. O. patagonica has been shown to successfully compete with bryozoan Watersipora sp. [67]. Serrano et al. [68] have reported a shift from macroalgal to O. patagonica dominance in the Mediterranean. Given that macroalgae are important primary producers, this shift may result in significant changes in ecosystem functioning.

Corals are currently facing worldwide declines as a result of stresses, including increasing sea temperatures, disease, and other anthropogenic disturbances [69-71]. Understanding the factors and characteristics that promote resilience in O. patagonica in the midst of environmental change may shed light into assessing and managing the long-term success of corals that are currently at risk.

\section{Conclusions}

Despite years of maintaining that Oculina patagonica is a recently introduced coral species in the Mediterranean, we found no genetic or historical demographic evidence to support that claim. Our results suggest that Mediterranean populations of O. patagonica have long been isolated from WA Oculina spp., and have only recently become invasive in the Mediterranean, most likely due to environmental changes. We advise against hastily identifying a previously unknown species as being introduced without detailed genetic analyses and comparisons to potential source populations. Accurate identification of species' invasive statuses will enable more effective research programs aimed at better understanding the mechanisms promoting the invasive nature of species, which can then lead to the implementation of efficient management plans.

\section{Methods}

\section{Sampling and genotyping}

Mediterranean samples $(n=66)$ of Oculina patagonica were collected from Spain, Italy, Greece, Lebanon, and Israel during the summers of 2011-13 (see Additional file 2: Table S1; Figure 1). Individual colonies were sampled by chipping off a small piece of skeleton containing coral tissue and preserving it in $95 \%$ ethanol. Samples were generally $10 \mathrm{~m}$ from conspecifics and not physically connected to them to avoid collecting clonemates.

Western North Atlantic Oculina spp. samples $(\mathrm{n}=56)$ consisted of a subset of populations along the coast of the eastern United States from Eytan et al. [23]. The four populations (North Carolina, Daytona Beach, Cape Florida, Panama City) were chosen to represent the two geographic genetic clusters (North Carolina and Daytona Beach = northern cluster; Cape Florida and Panama City = southern cluster) and include three nominal species: $O$. arbuscula, $O$. varicosa, and $O$. diffusa, although Eytan et al. [23] found no genetic differences among these named taxa. We also obtained 13 new samples of nominal species $O$. diffusa and 
O. varicosa from Bermuda. We will refer to these samples collectively as "Western Atlantic (WA) Oculina spp". All sampling was conducted by or with local collaborators in accordance with local and CITES regulations.

We extracted genomic DNA using QIAGEN DNeasy Kit following the manufacturer's protocols with the following modifications. We lysed tissues at $56^{\circ} \mathrm{C}$ overnight. We added $200 \mu \mathrm{l}$ elution buffer and incubated at room temperature for an hour prior to the final centrifuge step. All individuals were genotyped, either previously or in this study, for the mitochondrial cytochrome oxidase I (COI) gene and the coding region of five nuclear genes (see Additional file 4: Table S2). COI was genotyped using previously deigned primers [72]. Three of the nuclear genes (putatively: fatty acid elongase, elongation factor $1 \alpha$, and tachylectin-2 motif) were previously developed to assess subdivision in WA Oculina spp. populations [23], so only the 13 Bermuda and 66 Mediterranean samples were genotyped for these markers here. Two new nuclear markers (putatively: crystalline and S-adenosylmethionine synthetase) were developed using an expressed sequence tag (EST) library [23]; all samples were genotyped for these.

Polymerase chain reaction (PCR) amplifications were conducted in $25 \mu \mathrm{l}$ reactions consisting of $2.5 \mu \mathrm{l}$ of $10 \mathrm{x}$ buffer, $10 \mu \mathrm{M}$ of dNTPs and each primer, and $0.2 \mu \mathrm{l}$ of One TaqTM DNA polymerase (New England Biolabs Inc.). Amplifications were performed in a Bio-Rad T100 thermocyler under the conditions outlined by Eytan et al. [23]. Samples were sequenced in both directions using BigDye v3.1 on an ABI 3130XL at the Louisiana State University Genomics Facility. Sequences were aligned and edited using Geneious 4.5.5 [73]. Sequences obtained from Eytan et al. [23] were trimmed to align to sequences generated in this study. To resolve alleles in heterozygous individuals, we employed a Bayesian statistical method implemented in PHASE 2.1 [74-76]. Individuals with alleles that could not be phased to a probability $>90 \%$ were cloned using the Invitrogen TOPO TA kit following the manufacture's protocols. At least eight clones per reaction were sequenced to identify the two alleles present in a sample. The phased individuals derived from the cloning reactions were then added to the 'known' PHASE file and the data sets were re-analyzed. This process was repeated until the phase of all individual genotypes was recovered with $>90 \%$ probability. Individuals heterozygous for an insertion/deletion were resolved using CHAMPURU 1.0 [77]. In the end, we were able to successfully resolve all 122 individuals' multilocus genotypes.

To prevent clonal reproduction from skewing subdivision and genetic diversity measures, we removed individuals that shared a multilocus genotype with another individual in the same population. The final nuclear data set contained 105 individuals (see Additional file 2:
Table S1). Measures of genetic diversity for each nuclear marker were calculated in DnaSP [78,79] (see Additional file 4: Table S2). We tested each gene region for intralocus recombination using GARD implemented in $\mathrm{Hy}-$ Phy [80-82].

\section{Genetic diversity and population subdivision}

To visualize the relationships among alleles, we constructed haplotype networks for each locus using statistical parsimony implemented in TCS 1.21 [83]. These networks reveal how alleles for a particular gene are shared among individuals from different populations. We calculated allelic richness for all populations using FSTAT 2.9.3.2 [84] and calculated observed heterozygosity using GENODIVE [85]. To test whether Mediterranean populations harbor less genetic diversity than western Atlantic populations, we compared their average allelic richness and observed heterozygosities using two-sample one-tailed t-tests in GraphPad Prism 5. We performed similar comparisons between western Mediterranean (Spain and Italy) and eastern Mediterranean (Greece, Lebanon, and Israel) populations using two-sample two-tailed t-tests. To test for hierarchical genetic subdivision, we performed Analyses of Molecular Variance (AMOVA) implemented in GENODIVE [85] for all populations combined, and for only Mediterranean populations.

The Bayesian clustering analysis implemented in STRUCTURE [42] has been used often to infer species introductions and identify potential source populations [17]. Here, we used STRUCTURE 2.3.4 [42] to test whether O. patagonica populations in the Mediterranean are genetically similar to or distinct from WA Oculina spp. populations. We first analyzed all populations together, and then analyzed the pool of Mediterranean populations separately. We ran the program for 1 million MCMC steps and discarded the first 100,000 steps as burn-in. We used the more conservative admixture model with uncorrelated allele frequencies. We performed 10 iterations for each inferred number of genetic clusters, $k$. We used the Evanno method [43] implemented in STRUCTURE HARVESTOR [44] to determine the most likely number of genetic clusters, $k$, in the data. We also used STRUCTRAMA 2.0 [86] to explicitly estimate $k$ without $a$ prior assignment of a range of $k$, as in STRUCTURE. Each trial was run for 20 million generations, sampling every 100, discarding the first million as burn-in. We ran four chains at a temperature of 0.2 , and we employed a variety of model options.

\section{Divergence time}

We estimated the time of divergence between the western North Atlantic and Mediterranean populations using a coalescent-based method implement in IMa [45]. IMa uses Markov Chain Monte Carlo (MCMC) simulations of 
gene genealogies to estimate the divergence time $(t)$, genetic diversities $\left(\theta_{1}, \theta_{2}\right.$, and ancestral $\left.\theta\right)$ and migration rates $\left(m_{1}\right.$ and $\left.m_{2}\right)$ for two populations. To convert divergence time $(t)$, which is scaled by mutation in IMa, to years, we used the average nuclear substitution rate for Porites corals of $0.138 \%$ per Ma [87], since a rate for Oculina corals is unavailable, which was converted to a rate per locus per year for each marker (see Additional file 4: Table S2). Given that the sequence alignments showed sites with more than two variants and/or haplotype networks contained multiple reticulations, we used the finite-sites model for all genes.

We first performed several IMa runs, subsequently adjusting the upper bounds on the parameter priors, to determine the most efficient search parameters. We then ran four runs that differed only in the starting seed for $3,000,000$ total steps sampling every 100 steps for a total of 30,000 saved genealogies following a burn-in of 500,000 steps. The runs yielded similar results. We therefore combined the runs and estimated all parameters and performed nested model testing on the total saved genealogies in IMa's L mode (load trees). IMa analyses were conducted with high performance computational resources provided by Louisiana State University [88].

We recorded the maximum-likelihood estimate from the posterior probability distribution for divergence time, adjusted with a two year generation time [25] and its credibility interval based on the shortest parameter interval containing $90 \%$ of the area under the posterior distribution curve. Because the upper end of the posterior probability distribution did not drop to zero (Figure 5), we used the lower bound on the distribution as the parameter value at which the probability dropped to zero at the upper bound [89]. To evaluate all possible scenarios of divergence, which differ in the number of unique divergence parameters and therefore divergence complexity, we used model-based inference and model-based selection to calculate evidence ratios and rank all possible models [90-92].

\section{Fossil record search}

We searched museum collections for evidence of a fossil record of Oculina spp. in the eastern Atlantic and/or the Mediterranean. First, we explored the Smithsonian National Museum of Natural History's Department of Invertebrate Zoology records by performing a keyword search of Oculina on the IZ collections database website [93]. We also explored the Muséum National d'Histoire Naturelle Paléontologie collections database by performing a general search for Oculina on the collections website [94]. From both lists of matches, we searched for fossil specimens of Oculina spp. from eastern Atlantic and Mediterranean countries and recorded the catalog number, species name, location, and geologic age. Several of the specimens from the Smithsonian National Museum of
Natural History were observed during a visit to the museum in January 2013.

\section{Population expansion within the Mediterranean}

To test for expansion in the Mediterranean, we used LAMARC 2.0 [46], which estimates parameters including population growth rate using coalescent theory and Metropolis Monte Carlo sampling technique. Three replicates were each run using a Bayesian search strategy and a single final chain. Following a burn-in of 500,000, 5 million trees were sampled every 100 step. Three simultaneous searches were performed at heating temperatures of 1, 1.2, and 1.3, and a swap interval of 10. Trial runs were first conducted and the output files examined in the program TRACER 1.5 [95] to adjust the parameter bounds and assess the run. A "good run" was one in which both the effective sample size (ESS) values were great than 200 and trace plots for each parameter were stationary. LAMARC calculates the overall growth rate across all genes and replicates. Positive values of growth rate indicate that the population has been growing, while negative values indicate that it has been shrinking.

\section{Availability of supporting data}

Haplotypes for COI, p14, p62, and p302 for western North Atlantic Oculina spp. populations obtained by Eytan et al. [23] are available on GenBank [FJ966395-FJ966875]. Haplotypes generated here are available on The European Nucleotide Archive [LN613417-LN614380].

\section{Additional files}

Additional file 1: Figure S1. Photographs of Oculina spp. specimens.
A-D are Oculina spp. fossil specimens from the Smithsonian National
Museum of Natural History. A and B are O. patagonica from South
America (USNM 75199 and USNM 75205, respectively). C and D are O.
crassoramosa from France (USNM I 80807). E is a skeletal specimen of
extant O. patagonica from the eastern Mediterranean. F is a skeletal
specimen of extant O. diffusa from Panama City, Florida (USA).

Additional file 2: Table S1. Collection sites of all Oculina spp. samples used in this study.

Additional file 3: Figure S2. COI Neighbor-Joining Tree. Neighbor-joining tree constructed using COl haplotypes from western North Atlantic Oculina spp. populations and O. patagonica populations from the Mediterranean, with Solenastrea hyades as the outgroup. Numbers represent the number of individuals from each locality that share that haplotype. The tree shows that O. patagonica (bolded) shares the same haplotype common to most western North Atlantic Oculina spp.

Additional file 4: Table S2. Nuclear markers used to genotype all Oculina spp. samples in this study.

\section{Competing interests}

The authors declare that they have no competing interests.

\section{Authors' contributions}

Both authors conceived of the study and its design. KPL carried out some collections, generated all new genetic data, performed the genetic analyses, and drafted the manuscript. Both authors read, edited, and approved the final manuscript. 


\section{Acknowledgements}

We thank Samantha du Putron, Maoz Fine, Marshall Hayes, Greg Piniak, Maria Salomidi, Jose Templado, Brian Leydet, Aline Posbic and Vincent Posbic for their help collecting and obtaining tissue samples. We also thank Stephen Cairns and Tim Coffer for their assistance at the Smithsonian National Museum of Natural History. Funding was provided by Sigma Xi Grants-in-Aid of Research Program and Lerner-Gray Grant for Marine Research awarded to $\mathrm{KPL}$, and funds from LSU's Department of Biological Sciences.

\section{Received: 14 October 2014 Accepted: 21 April 2015 \\ Published online: 05 May 2015}

\section{References}

1. Baskin Y: A plague of rats and rubbervines: the growing threat of species invasions. Washington: Island Press; 2002

2. Ricciardi A, Neves RJ, Rasmussen JB. Impending extinctions of North American freshwater mussels (Unionoida) following the zebra mussel (Dreissena polymorpha) invasion. J Anim Ecol. 1998;67:613-19.

3. Morales CL, Arbetman MP, Cameron SA, Aizen MA. Rapid ecological replacement of a native bumble bee by invasive species. Front Ecol Environ. 2013;11:529-34.

4. Kenis M, Auger-Rozenberg M-A, Roques A, Timms L, Péré C, Cock MJ, et al. Ecological effects of invasive alien insects. J Biol Invasions. 2009;11:21-45.

5. Turon X, Tarjuelo I, Duran S, Pascual M. Characterising invasion processes with genetic data: an Atlantic clade of Clavelina lepadiformis (Ascidiacea) introduced into Mediterranean harbours. Hydrobiologia. 2003:503:29-35.

6. Genner MJ, Michel E, Erpenbeck D, De Voogd N, Witte F, POINTIER JP. Camouflaged invasion of lake Malawi by an oriental gastropod. Mol Ecol. 2004;13:2135-41.

7. Zenetos A, Çinar M, Pancucci-Papadopoulou M, Harmelin J, Furnari G, Andaloro $F$, et al. Annotated list of marine alien species in the Mediterranean with records of the worst invasive species. Mediterr Marine Sci. 2005;6:63-118.

8. Carlton JT: Biological invasions and cryptogenic species. Ecology 1996;77:1653-55

9. Concepcion G, Kahng S, Crepeau M, Franklin E, Coles S, Toonen R. Resolving natural ranges and marine invasions in a globally distributed octocoral (genus Carijoa). Mar Ecol Prog Ser. 2010;401:113-27.

10. Hawryshyn J, Rühland KM, Julius M, Smol JP. Absence of evidence is not evidence of absence: Is Stephanodicus binderanus (Bacillariophyceae) an exotic species in the Great Lakes region? J Phycol. 2012;48:270-4.

11. Taylor BW, Bothwell ML. The origin of invasive microorganisms matters for science, policy, and management: the case of didymosphenia geminata. Bioscience. 2014;64:531-8.

12. Geller JB. Decline of a native mussel masked by sibling species invasion. Conserv Biol. 1999;13:661-4.

13. Simberloff D. 2011. Native invaders. In: Simberloff D and Rejmánek M (Eds). Encyclopedia of biological invasions. Berkeley and Los Angeles, CA: University of California Press.

14. Carey MP, Sanderson BL, Barnas KA, Olden JD. Native invaders - challenges for science, management, policy, and society. Front Ecol Environ. 2012;10:373-81.

15. Hierro JL, Villarreal D, Eren Ö, Graham JM, Callaway RM. Disturbance facilitates invasion: the effects are stronger abroad than at home. Am Nat. 2006;168:144-56

16. Simberloff D, Souza L, Nunez MA, Barrios-Garcia MN, Bunn W. The natives are restless, but not often and mostly when disturbed. Ecology. 2012;93:598-607.

17. Perdereau E, Bagnères AG, Bankhead Dronnet S, Dupont S, Zimmermann M,

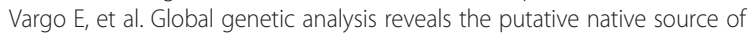
the invasive termite, Reticulitermes flavipes, in France. Mol Ecol. 2013;22:1105-19.

18. Kim KS, Cano-Ríos P, Sappington TW. Using genetic markers and population assignment techniques to infer origin of boll weevils (Coleoptera: Curculionidae) unexpectedly captured near an eradication zone in Mexico. Environ Entomol. 2006;35:813-26.

19. Wares JP, Goldwater DS, Kong BY, Cunningham CW. Refuting a controversial case of a human-mediated marine species introduction. Ecol Lett. 2002:5:577-84.

20. Mun J, Bohonak AJ, Roderick GK. Population structure of the pumpkin fruit fly Bactrocera depressa (Tephritidae) in Korea and Japan: Pliocene allopatry or recent invasion? Mol Ecol. 2003;12:2941-51.
21. Brouat C, Tollenaere C, Estoup A, Loiseau A, Sommer S, Soanandrasana R, et al. Invasion genetics of a human commensal rodent: the black rat Rattus rattus in Madagascar. Mol Ecol. 2014;23:4153-67.

22. Miller MW, Hay ME: Coral-seaweed-grazer-nutrient interactions on temperate reefs. Ecological Monographs 1996;66:323-44

23. Eytan Rl, Hayes M, Arbour-Reily P, Miller M, Hellberg ME. Nuclear sequences reveal mid-range isolation of an imperilled deep-water coral population. Mol Ecol. 2009:18:2375-89.

24. Zibrowius H. Oculina patagonica, scléractiniaire hermatypique introduit en Méditerranée. Helgoländer Meeresun. 1974;26:153-73.

25. Fine M, Zibrowius H, Loya Y. Oculina patagonica: a non-lessepsian scleractinian coral invading the Mediterranean Sea. Mar Biol. 2001;138:1195-203.

26. Schwindt E, López Gappa J, Raffo MP, Tatián M, Bortolus A, Orensanz JM, et al. Marine fouling invasions in ports of Patagonia (Argentina) with implications for legislation and monitoring programs. Mar Environ Res. 2014;99:60-8

27. Zibrowius H, Ramos A. Oculina patagonica, scléractiniaire exotique en Méditerranée- nouvelles observations dans le Sud-Est de l'Espagne. Rapp Comm Int Pour l'Explor Sci Mer Méditerr [CIESM]. 1983;28:297-301.

28. Bitar G, Zibrowius H. Scleractinian corals from Lebanon, eastern Mediterranean, including a non-lessepsian invading species (cnidaria: scleractinia). Sci Mar. 1997;61:227-31.

29. Salomidi M, Bellou N, Pancucci-Papadopoulou MA, Zibrowius H: First observation of an invasive scleractinian coral in Greek waters. In Poster presented at the 41st European Marine Biology Symposium, Cork. 2006: 4-8.

30. Sartoretto S, Harmelin J-G, Bachet F, Bejaoui N, Lebrun O, Zibrowius H. The alien coral Oculina patagonica De Angelis, 1908 (Cnidaria, Scleractinia) in Algeria and Tunisia. Aquat Invasions. 2008;3:173-80.

31. Izquierdo A, Loya A, Diaz-Valdez M, Ramos-Espla AA: Non-indigenous species at the Alicante harbour(SE-Spain): Oculina patagonica de Angelis, 1908 and Botrycapulus aculeatus (Gmelin, 1791). Rapports Commission Internationale pour l'Exploration Scientifique de la Mer Méditerranée [CIESM]. 2007:38:506.

32. Serrano E, Coma R, Ribes M, Weitzmann B, Garcia M, Ballesteros E. Rapid northward spread of a zooxanthellate coral enhanced by artificial structures and sea warming in the western Mediterranean. PLoS One. 2013;8:e52739.

33. Rubio-Portillo E, Vázquez-Luis M, Izquierdo Muñoz A, Ramos Esplá AA. Distribution patterns of alien coral Oculina patagonica De Angelis D'Ossat, 1908 in western Mediterranean Sea. J Sea Res. 2014:85:372-8.

34. Salomidi M, Katsanevakis S, Issaris Y, Tsiamis K, Katsiaras N. Anthropogenic disturbance of coastal habitats promotes the spread of the introduced scleractinian coral Oculina patagonica in the Mediterranean Sea. Biol Invasions. 2013:15:1961-71.

35. Fine M, Loya Y. The coral Oculina patagonica: a new immigrant to the Mediterranean coast of Israel. Israel J Zool. 1995;41:81.

36. Ballesteros E. Addicions a la fauna d'invertebrats bentonics marins de l'Arxipelag de Cabrera (Illes Balears, Mediterrania Occidental). Butll Societat Història Natural Balears. 1998:41:41-8.

37. Cvitković I, Despalatović M, Nikolić V, Žuljević A: The first record of Oculina patagonica (Cnidaria, Scleractinia) in the Adriatic Sea. Acta Adriatica 2013;54:87-92.

38. Çinar ME, Bilecenoglu M, Öztürk B, Can A. New records of alien species on the Levantine coast of Turkey. Aquat Invasions. 2006;1:84-90.

39. Fukami H, Budd AF, Paulay G, Solé-Cava A, Chen CA, Iwao K, et al, Conventional taxonomy obscures deep divergence between Pacific and Atlantic corals. Nature. 2004:427:832-5

40. Pinzon JH, LaJeunesse TC. Species delimitation of common reef corals in the genus Pocillopora using nucleotide sequence phylogenies, population genetics and symbiosis ecology. Mol Ecol. 2011;20:311-25.

41. Hellberg ME. No variation and low synonymous substitution rates in coral mtDNA despite high nuclear variation. BMC Evol Biol. 2006;6:24.

42. Pritchard JK, Stephens M, Donnelly P. Inference of population structure using multilocus genotype data. Genetics. 2000;155:945-59.

43. Evanno G, Regnaut S, Goudet J. Detecting the number of clusters of individuals using the software STRUCTURE: a simulation study. Mol Ecol. 2005; 14:2611-20

44. Earl DA. STRUCTURE HARVESTER: a website and program for visualizing STRUCTURE output and implementing the Evanno method. Conserv Genet Resour. 2012;4:359-61.

45. Hey J, Nielsen R. Integration within the Felsenstein equation for improved Markov chain Monte Carlo methods in population genetics. Proc Natl Acad Sci. 2007;104:2785-90. 
46. Kuhner MK. LAMARC 2.0: maximum likelihood and Bayesian estimation of population parameters. Bioinformatics. 2006;22:768-70.

47. Goodbody Gringley G, Woollacott RM, Giribet G. Population structure and connectivity in the Atlantic scleractinian coral Montastraea cavernosa (Linnaeus, 1767). Mar Ecol. 2012;33:32-48.

48. Meinesz A, Boudouresque C-F. Sur l'origine de Caulerpa taxifolia en Méditerranée. Comptes Rendus 'Acad Sci Série 3Sci. 1996;319:603-14.

49. Jousson O, Pawlowski J, Zaninetti L, Meinesz A, Boudouresque C. Molecular evidence for the aquarium origin of the green alga Caulerpa taxifolia introduced to the Mediterranean Sea. Mar Ecol Prog Ser. 1998;172:275-80.

50. Galil B. Taking stock: inventory of alien species in the Mediterranean Sea. Biol Invasions. 2009;11:359-72.

51. Lejeusne C, Chevaldonne P, Pergent-Martini C, Boudouresque CF, Perez T. Climate change effects on a miniature ocean: the highly diverse, highly impacted Mediterranean Sea. Trends Ecol Evol. 2010;25:250-60.

52. Bernecker M, Weidlich O: Azooxanthellate corals in the Late MaastrichtianEarly Paleocene of the Danish basin: bryozoan and coral mounds in a boreal shelf setting. In Cold-water corals and ecosystems. Springer Berlin Heidelberg; 2005: 3-25

53. Cahuzac B, Chaix C: Les faunes de coraux (Anthozoaires Scléractiniaires) de la façade atlantique française au Chattien et au Miocène. Ciências da Terra 1993;12:57-69

54. Hsü K, Ryan W, Cita M. Late Miocene desiccation of the Mediterranean Nature. 1973;242:240-4.

55. Krijgsman W, Hilgen F, Raffi I, Sierro F, Wilson D. Chronology, causes and progression of the Messinian salinity crisis. Nature. 1999;400:652-5.

56. Patarnello T, Volckaert FA, Castilho R. Pillars of Hercules: is the AtlanticMediterranean transition a phylogeographical break? Mol Ecol. 2007;16:4426-44

57. Wangensteen OS, Turon X, Pérez-Portela R, Palacín C. Natural or naturalized? Phylogeography Suggests Abundant Arbacia Lixula Recent Colonizer Mediterr PloS One. 2012;7:e45067.

58. Boekschoten G, Best MB. Fossil and recent shallow water corals from the Atlantic islands off western Africa. Zool Meded. 1988:62:99-112.

59. Monteiro J, Almeida C, Freitas R, Delgado A, Porteiro F, Santos R: Coral assemblages of Cabo Verde: preliminary assessment and description. Proceedings of the 11th International Coral Reef Symposium, Fort Lauderdale, Florida. 2008;7(11):1416-19.

60. Wells JW: New genera of Mesozoic and Cenozoic corals. Journal of Paleontology 1937;11:73-77

61. Kai S, Sakai K. Effect of colony size and age on resource allocation between growth and reproduction in the corals Goniastrea aspera and Favites chinensis. Mar Ecol Prog Ser. 2008;354:133.

62. Kitahara MV, Cairns SD, Stolarski J, Blair D, Miller DJ. A comprehensive phylogenetic analysis of the Scleractinia (Cnidaria, Anthozoa) based on mitochondrial CO1 sequence data. PLoS One. 2010;5:e11490.

63. Armoza-Zvuloni R, Segal R, Kramarsky-Winter E, Loya Y. Repeated bleaching events may result in high tolerance and notable gametogenesis in stony corals: Oculina patagonica as a model. Mar Ecol Prog Ser. 2011;426:149-59.

64. Bothwell ML, Taylor BW, Kilroy C: The Didymo story: The role of low dissolved phosphorus in the formation of Didymosphenia geminata blooms. Diatom Research 2014;29:1-8

65. Hoeksema B, Vicente OO: First record of the Central Indo-Pacific reef coral Oulastrea crispata in the Mediterranean Sea. Mediterranean Marine Science 2014;15:429-36.

66. Sorte CJ, Williams SL, Carlton JT. Marine range shifts and species introductions: comparative spread rates and community impacts. Glob Ecol Biogeogr. 2010;19:303-16.

67. Fine M, Loya Y. Alternate coral-bryozoan competitive superiority during coral bleaching. Mar Biol. 2003;142:989-96.

68. Serrano E, Coma R, Ribes M: A phase shift from macroalgal to coral dominance in the Mediterranean. Coral Reefs 2012;31:1199

69. Aronson RB, Bruno JF, Precht WF, Glynn PW, Harvell CD, Kaufman L, et al. Causes of coral reef degradation. Science. 2003;302:1502-4. author reply 1502-1504.

70. Pandolfi JM, Bradbury RH, Sala E, Hughes TP, Bjorndal KA, Cooke RG, et al. Global trajectories of the long-term decline of coral reef ecosystems. Science. 2003:301:955-8.

71. Hoegh Guldberg O, Mumby PJ, Hooten AJ, Steneck RS, Greenfield P, Gomez $E$, et al. Coral reefs under rapid climate change and ocean acidification. Science. 2007:318:1737-42.
72. Folmer O, Black M, Hoeh W, Lutz R, Vrijenhoek R. DNA primers for amplification of mitochondrial cytochrome c oxidase subunit I from diverse metazoan invertebrates. Mol Mar Biol Biotechnol. 1994;3:294-9.

73. Drummond AJ, B. A, Cheung M, Heled J, Kearse M, Moir R, Stones-Havas S, Thierer T, Wilson A: Geneious version 4.5.5. Available from URL: http:// www.geneious.com/ 2010.

74. Stephens M, Smith NJ, Donnelly P. A new statistical method for haplotype reconstruction from population data. Am J Hum Genet. 2001;68:978-89.

75. Stephens M, Donnelly P. A comparison of bayesian methods for haplotype reconstruction from population genotype data. Am J Hum Genet. 2003;73:1162-9.

76. Stephens $M$, Scheet $P$. Accounting for decay of linkage disequilibrium in haplotype inference and missing-data imputation. Am J Hum Genet. 2005;76:449-62.

77. Flot JF. Champuru 1.0: a computer software for unraveling mixtures of two DNA sequences of unequal lengths. Mol Ecol Notes. 2007;7:974-7.

78. Rozas J, Rozas R. DnaSP, DNA sequence polymorphism: an interactive program for estimating population genetics parameters from DNA sequence data. Comput Appl Biosci. 1995;11:621-5.

79. Librado P, Rozas J. DnaSP v5: a software for comprehensive analysis of DNA polymorphism data. Bioinformatics. 2009;25:1451-2.

80. Pond SL, Frost SD, Muse SV. HyPhy: hypothesis testing using phylogenies. Bioinformatics. 2005;21:676-9.

81. Pond SLK, Posada D, Gravenor MB, Woelk CH, Frost SD. Automated phylogenetic detection of recombination using a genetic algorithm. Mol Biol Evol. 2006;23:1891-901.

82. Delport W, Poon AF, Frost SD, Kosakovsky Pond SL. Datamonkey 2010: a suite of phylogenetic analysis tools for evolutionary biology. Bioinformatics. 2010;26:2455-7.

83. Clement M, Posada D, Crandall KA. TCS: a computer program to estimate gene genealogies. Mol Ecol. 2000;9:1657-9.

84. Goudet J. FSTAT (version 1.2): a computer program to calculate F-statistics. J Hered. 1995:86:485-6.

85. Meirmans PG, Van Tienderen PH. GENOTYPE and GENODIVE: two programs for the analysis of genetic diversity of asexual organisms. Mol Ecol Notes. 2004:4:792-4.

86. Huelsenbeck JP, Andolfatto P. Inference of population structure under a Dirichlet process model. Genetics. 2007;175:1787-802.

87. Prada C, DeBiasse M, Neigel J, Yednock B, Stake J, Forsman Z, Baums I, Hellberg M: Genetic species delineation among branching Caribbean Porites corals. Coral Reefs 2014;33:1019-30

88. Louisiana State University High Performance Computational Resources [http://www.hpc.lsu.edu]

89. McGovern TM, Keever CC, Saski CA, Hart MW, Marko PB. Divergence genetics analysis reveals historical population genetic processes leading to contrasting phylogeographic patterns in co-distributed species. Mol Ecol. 2010;19:5043-60

90. Anderson DR: Model based inference in the life sciences: a primer on evidence. New York Springer; 2008

91. Carstens BC, Stoute HN, Reid NM. An information-theoretical approach to phylogeography. Mol Ecol. 2009;18:4270-82.

92. Carstens Lab: Software, Scripts, and Publication Resources [http:// carstenslab.org.ohio-state.edu/OSU/Software.html]

93. Smithsonian National Museum of Natural History's Department of Invertebrate Zoology IZ Collections Database [http://collections.nmnh. si.edu/search/iz/]

94. Muséum National d'Histoire Naturelle Paléontologie Collections Database [http://www.mnhn.fr/fr/collections/ensembles-collections/paleontologie]

95. Rambaut A, Drummond AJ: Tracer v. 1.5. Computer program and documentation distributed by the authors at http://beast.bio.ed.ac.uk/ Tracer. 2007 